\title{
Scindapsus aureus as Potential Biomarker of Polluted Environment
}

Cruz $\mathbf{M}^{1,2}$, Fuentes ME${ }^{1,2}$, Khouri $E^{1,2}$, Rollan $\mathbf{G}^{3}$ and Gonzalez $\mathrm{SN}^{1,2^{*}}$

${ }^{1}$ Department of Public Health, National University of Tucumán, Argentina

${ }^{2}$ Department of Public Health, Inbiofal-CCT Conicet Tucumán, Argentina

${ }^{3}$ Department of Public Health Cerela-CCT Conicet Tucumán, Argentina

\begin{abstract}
Living organisms are subject to different environmental effects, including physical, biological or chemical factors. In front of pollution, which can be defined as an aggression, the organisms must be adapted to survive. In microsomal fraction of cells, there is an oxidase enzymatic complex, whose central element is the cytochrome P450, able to eliminate certain harmful substances. The main action of P450 system is to introduce a functional group to foreign lipophilic compound, which deveins water-soluble and it excretion was facilitated. In this study a method, originally designed to measure P450 activity in animal cells, was modified and adapted for application in plant cells from contaminated environments. Scindapsus aureus also namely Epipremnum aureum, is considered between the best plants with air purification ability. The aim of this work was to study the effect of polluted environments on this plant species, to determining its potential use as contamination biomarker. The results indicated that P450 activity was manifested only in saturated cell-free extract dialysates from those plants exposed to high contamination during periods longer than 30 days. The induction of this enzyme, with detoxificant power, could depend of pollutant type, and/or exposure times. Few studies using plants as air contamination biomarker by $\mathrm{CO}$ were conducted. The results obtained allow recommend susceptible species for quantifying indirect pollution in offices, laboratories, factories, where the workers are exposed $8 \mathrm{~h}$ daily, during several years.
\end{abstract}

Keywords: Biomarkers; Monoxide carbon; P450 activity; Polluting agents; Vegetal cells

\section{Introduction}

Living organisms are subject to different environmental effects, including physical, biological or chemical factors. In front of pollution, which can be defined as an aggression, the organisms must be adapted to survive. Chemicals of different origins can reach the animals by oral or cutaneous via. Synthetic products, toxic, because living things or the environment can not eliminate, are known as xenobiotics.

In microsomal fraction of cells, there is an oxidase enzymatic complex, whose central element is the cytochrome P450, located in a structure involved in transport (endoplasmic reticulum) and also in mitochondria (energy-producing centers). This complex, whose name corresponds to the ability to absorb light at $450 \mathrm{~nm}$, eliminates certain hydrophobic substances. The danger is defined by potential retention of these compounds into biological membranes. P450 mitochondrial enzymes are generally involved in synthesis and metabolism of endogenous substances, while P450 endoplasmic reticulum usually metabolizes foreign substances, medicines and environmental pollutants $[1,2]$.

Xenobiotics, generally fat soluble, can cross biological membranes and are accumulated in fatty tissue. When they reach specific concentrations, interfere with normal metabolic processes or with toxicological/pharmacological responses. The main action of P450 system is to introduce a functional group to foreign lipophilic compound, which deveins water-soluble and it excretion was facilitated.

The tree flora can trap and retain different chemicals from the environment, including some of recognized hazard, which represents an example of biodetoxificación, in this case elimination of xenobiotics. The elimination of toxic, carried out by a biotransformation process, is catalyzed by enzymes. According to Levitt [3], air pollution stress on vegetation is defined as the existence of an atmospheric pollutant able to induce a chemical or physical in the plant. Since gaseous pollutants must penetrate the leaf interior to elicit damage, the existence of a stress does not result necessarily in leaf alteration. If the pollutant is excluded from leaves, the plant avoids the stress. This is pollution stress avoidance. When pollutant is absorbed, two factors determine leaf response: the internal pollutant concentration and the biochemical threshold level of tolerance for the pollutant or its toxic derivatives. If the internal concentration exceeds the threshold level, leaf damage may occur. A physiological damage (elastic damage) can be reversible; however prolonged time under pollutant action may define an irreversible situation. The uptake rate is a function of the pollutant concentration gradient from the leaf exterior to its interior and the resistance to gaseous flow experienced by the pollutant along the diffusion.

Olry et al. [4] have proposed a medium-throughout methodology to screen for potential substrates of orphan P450 mono-oxygenases. The technique is based on a commercially available microplate system, which detects the oxygen consumed by the catalytic reaction via an oxygen-sensing fluorophore. It is optimized using as a model CYP73A1, the cinnamic acid hydroxylase from Helianthus tuberosus, expressed in yeast. These authors considered this procedure as suitable not only for the detection and real-time monitoring, but also for the quantitative evaluation of enzyme activity.

Omura and Sato technique was designed to measure P450 activity in animal cells, specifically liver cells. In our study this methodology was modified and adapted for application in plant cells from contaminated environments.

*Corresponding author: Silvia Nelina Gonzalez, Department of Public Health National University of Tucumán, Argentina, Tel: +543814248169; E-mail: sgonzalez@fbqf.unt.edu.ar

Received May 05, 2018; Accepted May 23, 2018; Published May 29, 2018

Citation: Cruz M, Fuentes M, Khouri E, Rollan G, Gonzalez SN (2018) Scindapsus aureus as Potential Biomarker of Polluted Environment. J Pollut Eff Cont 6: 221. doi: $10.4172 / 2375-4397.1000221$

Copyright: $(2018$ Cruz M, et al. This is an open-access article distributed under the terms of the Creative Commons Attribution License, which permits unrestricted use, distribution, and reproduction in any medium, provided the original author and source are credited. 
Scindapsus aureus, also namely Epipremnum aureum, is considered between the best plants with air purification ability. Scientists are finding several species to be surprisingly useful in absorbing potentially harmful gases and cleansing air inside buildings [5].

The aim of this work was to study the effect of polluted environments on Scindapsus aureus, to determining its potential use as contamination biomarker.

\section{Materials and Methods}

The samples used were leaves of Scindapsus aureus (common name in Argentine: potho). The plants were placed in areas with and without exposition to contaminant compounds. Plants highly exposed to environmental pollutants: smoking areas; totally covered parking for hourly; totally covered garage for bus.

Plants located in healthy environmental areas: private big gardens

Time of exposure in days: $7\left(\mathrm{~T}_{1}\right) ; 10\left(\mathrm{~T}_{2}\right) ; 14\left(\mathrm{~T}_{3}\right) ; 20\left(\mathrm{~T}_{4}\right)$ and $40\left(\mathrm{~T}_{5}\right)$

Protein levels in samples, were determined by Bradford Method [6]

P450 activity was studied by Omura and Sato (1964) but this test was adapted for vegetable cells in our laboratory

(original method was designed for animal cells).

\section{Method description}

From each environment, leaves of Scindapsus aureus (100g) were put in $200 \mathrm{~mL}$ buffer Tris-EDTA ( $\mathrm{pH} \mathrm{7.5)}$ and pressed during 10 min at maximum speed. Then this mixture was filtered by passage through gauze and the obtained filtrated, identified as homogenate (H) was fractioned in 4 portions and kept at $4^{\circ} \mathrm{C}$. Two fractions for determining proteins and $\mathrm{P} 450$ activity and the two remaining were used as duplicating assay. $\mathrm{H}$ fraction for $\mathrm{P} 450$ activity was centrifuged $\left(4^{\circ} \mathrm{C} ; 14000 \mathrm{rpm} ; 15 \mathrm{~min}\right.$.) and the resulting supernatant constituted the cell-free extract (CFE), which was fractioned in three portions: one for protein determination, other for enzymatic activity (P450). The remaining fraction was saturated with ammonium sulphate (saturation was conducted, under refrigeration at $4^{\circ} \mathrm{C}$ ), by slow addition of salt and agitation after achieving saturation. This saturation process required 30 min. Saturated cell-free extract was centrifuged $\left(4^{\circ} \mathrm{C} ; 14000 \mathrm{rpm} ; 15\right.$ $\mathrm{min}$ ) and the supernatant identified as SCFE was used to determining protein levels and $\mathrm{P} 450$ activity. The precipitate, resuspended in buffer Tris $10 \mathrm{mM}$-EDTA $1 \mathrm{mM}(\mathrm{pH} 7.5)$ and dialysate in the same solution (diluted 1/10) during 12 hours, constituted the saturated cell-free extract dialysate (SCFED). In this fraction protein levels and P450 activity were also measured.

Each sample ( $1 \mathrm{mg} / \mathrm{mL}$ protein) in that solution Tris EDTA ( $\mathrm{pH} 7.5)$ was reduced with a few milligrams of solid $\mathrm{Na}_{2} \mathrm{~S}_{2} \mathrm{O}_{4}$ (crystals). Then, $\mathrm{CO}$ was carefully bubbled through the sample for about $1 \mathrm{~min}$ for saturating it with the gas. $\mathrm{CO}$ was generated from $10 \mathrm{~mL}$ of concentrated sulfuric acid and $4 \mathrm{~mL}$ of pure formic acid.

All microsomal preparations were measured in a Cary model 14 spectrophotometer ( $1 \mathrm{~cm}$ optical path cuvette) for scanning its spectral range ( $400-600 \mathrm{~nm}$ ). The table informs only $\lambda$ values corresponding to emissions obtained from all samples of each experiment.

Control sample was obtained by replacing the crushed leaves solution by distilled water. Each experiment was made by duplicate. The informed results, in all cases, are the mean values of three experiments carried out on different occasions.

\section{Results and Discussion}

The results obtained from leaf cell extracts of Scindapsus aureus located in different environments are expressed in Table 1. The samples collected from Scindapsus aureus located in smoking areas and private big gardens showed no P450 enzymatic activity after exposure times considered in this study (7-40 days).

The assays performed in our work have shown results indicating that P450 activity was manifested only in saturated cell-free extract dialysates from those plants exposed to high contamination during periods longer than 30 days. Table 1 totally covered parking for hourly $\left(\lambda_{450}: 3,054 \pm 0,025\right)$ and totally covered garage for bus $\left(\lambda_{450}: 2,894 \pm\right.$ $0,017)$.

The induction of this enzyme, with detoxificant power on carcinogens, pesticides, carbon monoxide (CO), could depend of pollutant type, and/or exposure times. In our study the high contamination was specifically due to $\mathrm{CO}$ because parking and garages (totally covered) were previously studied, in this way, during several years by Khouri [7]. In this thesis was determined that polluted areas reached $\mathrm{CO}$ in levels of $33.35 \pm 1.91 \mathrm{ppm}$, while totally covered garages for bus registered $15.00 \pm 1.23 \mathrm{ppm}$ for the same gas.

Rodríguez et al. [8] have considered that the study of CYP450 family polymorphism can be a very useful marker not only in therapeutics, but in cytotoxic and carcinogenic studies, in relation to exposure of compounds that we consider harmful to humans, such as pesticides, additives, drugs, among others.

Tabrez and Ahmad [9] have studied Cytochrome P450 system as potential biomarkers of certain toxicants and they concluded that the selected isozymes of CYP450 system: pentoxy resorufin-o-deethylase (PROD), N-nitroso dimethyl amine demethylase (NDMA-d) and ethoxy resorufin-o-deethylase (EROD) can act as potent biomarkers in plant system for assessing the trichloroethylene (TCE) pollution.

The P450 genes are found in the genomes of virtually all organisms, but their number has exploded in plants and chemical defense seems to be a major reason for $\mathrm{P} 450$ diversification. Their amino-acid sequences are extremely diverse, with levels of identity as low as $16 \%$ in some cases [10].

Bak et al. [11] informed 244 cytochrome P450 genes (and 28 pseudogenes) in the Arabidopsis genome. P450s thus form one of the largest gene families in plants. Contrary to what was initially thought, this family diversification results in very limited functional redundancy and seems to mirror the complexity of plant metabolism. P450s sometimes share less than $20 \%$ identity and catalyze extremely diverse reactions leading to the precursors of several structural macromolecules (lignin, cutin, suberin and sporopollenin). The mechanisms of gene duplication and diversification are getting better understood and together with coexpression data provide leads to functional characterization.

The share of $\mathrm{P} 450$ genes in each plant genome is estimated to be up to $1 \%$. This implies that the diversification of $\mathrm{P} 450$ has made a significant contribution to the ability to acquire the emergence of new metabolic pathways during land plant evolution [12].

Any plant or environmental factor affecting either magnitude of the concentration gradient or resistance component alters the absorption rate of the pollutant. It is logical to suggest that disparate susceptibilities to equivalent pollutant dosage between species, individuals and leaves of the same plant result, in part, from leaf morphology variation. Research to date has largely ignored leaf morphology and boundary layer thickness as determinants of leaf susceptibility to air pollution [13]. 


\begin{tabular}{|c|c|c|c|c|c|}
\hline \multirow{2}{*}{$\begin{array}{c}\text { Samples obtained from } \\
\text { different exposure times } \\
\text { Homogenates }\end{array}$} & \multirow{2}{*}{$\lambda$ scan for emission spectrum } & \multicolumn{4}{|c|}{ Absorbance measurements } \\
\hline & & private big gardens & smoking areas & $\begin{array}{l}\text { Totally covered parking } \\
\text { for hourly }\end{array}$ & $\begin{array}{l}\text { totally covered } \\
\text { garage for bus }\end{array}$ \\
\hline $\mathrm{H} 1$ & 430 & $0.107 \pm 0.001$ & $0.119 \pm 0.003$ & $0.109 \pm 0.007$ & $0.114 \pm 0.001$ \\
\hline $\mathrm{H} 2$ & 420 & $0.105 \pm 0.003$ & $0.109 \pm 0.005$ & $0.111 \pm 0.003$ & $0.107 \pm 0.005$ \\
\hline $\mathrm{H} 3$ & 425 & $0.101 \pm 0.007$ & $0.115 \pm 0.003$ & $0.103 \pm 0.005$ & $0.107 \pm 0.007$ \\
\hline $\mathrm{H} 4$ & 418 & $0.113 \pm 0.002$ & $0.103 \pm 0.007$ & $0.112 \pm 0.005$ & $0.114 \pm 0.003$ \\
\hline H5 & 427 & $0.115 \pm 0.003$ & $0.117 \pm 0.005$ & $0.113 \pm 0.009$ & $0.104 \pm 0.002$ \\
\hline \multicolumn{6}{|c|}{ Cell-free extracts } \\
\hline CFE1 & 430 & $2.007 \pm 0.005$ & $2.018 \pm 0.014$ & $2.048 \pm 0.013$ & $2.037 \pm 0.009$ \\
\hline CFE2 & 420 & $2.015 \pm 0.007$ & $2.165 \pm 0.011$ & $2.765 \pm 0.013$ & $2.266 \pm 0.015$ \\
\hline CFE3 & 414 & $2.141 \pm 0.016$ & $2.051 \pm 0.012$ & $2.552 \pm 0.017$ & $2.225 \pm 0.012$ \\
\hline CFE4 & 425 & $2.017 \pm 0.008$ & $2.039 \pm 0.015$ & $2.789 \pm 0.023$ & $2.773 \pm 0.011$ \\
\hline CFE5 & 418 & $2.276 \pm 0.014$ & $2.369 \pm 0.013$ & $2.696 \pm 0.019$ & $2.696 \pm 0.016$ \\
\hline \multicolumn{6}{|c|}{ Satured cell-free extracts } \\
\hline SCFE1 & 430 & $2.008 \pm 0.007$ & $2.025 \pm 0.009$ & $2.078 \pm 0.013$ & $2.057 \pm 0.009$ \\
\hline SCFE2 & 420 & $2.053 \pm 0.005$ & $2.244 \pm 0.013$ & $2.785 \pm 0.015$ & $2.187 \pm 0.015$ \\
\hline SCFE3 & 425 & $2.052 \pm 0.003$ & $2.125 \pm 0.007$ & $2.725 \pm 0.019$ & $2.801 \pm 0.017$ \\
\hline SCFE4 & 434 & $2.355 \pm 0.021$ & $2.009 \pm 0.027$ & $2.809 \pm 0.017$ & $2.777 \pm 0.021$ \\
\hline SCFE5 & 440 & $2.005 \pm 0.001$ & $2.055 \pm 0.015$ & $2.095 \pm 0.016$ & $2.174 \pm 0.007$ \\
\hline \multicolumn{6}{|c|}{ Satured cell-free extract dialysates } \\
\hline SCFED1 & 430 & $1.863 \pm 0.006$ & $1.733 \pm 0.019$ & $1.986 \pm 0.005$ & $2.015 \pm 0.014$ \\
\hline SCFED2 & 420 & $1.753 \pm 0.005$ & $2.154 \pm 0.003$ & $2.608 \pm 0.013$ & $1.878 \pm 0.011$ \\
\hline SCFED3 & 427 & $2.007 \pm 0.013$ & $2.053 \pm 0.012$ & $2.648 \pm 0.021$ & $2.503 \pm 0.005$ \\
\hline SCFED4 & 434 & $2.145 \pm 0.011$ & $1.789 \pm 0.007$ & $2.815 \pm 0.014$ & $2.464 \pm 0.019$ \\
\hline SCFED5 & 450 & -- & -- & $3.054 \pm 0.025$ & $2.894 \pm 0.017$ \\
\hline
\end{tabular}

Note: Sub-indices indicate the different exposure times: $1=7$ days; $2=10$ days; $3=14$ days; $4=20$ days; $5=40$ days. Each experiment was made by duplicate and the expressed results are mean values of three experiments carried out on different occasions

Table 1: Absorbance values obtained from leaf cell extracts of Scindapsus aureus exposed to different environments.

Wolverton et al. [5] have evaluated leaves, roots, soil, and associated microorganisms of plants as a possible means of reducing indoor air pollutants. This study focused the use of plant systems for removing high concentrations of indoor air pollutants such as cigarette smoke and organic solvents. Some plants considered included species from Family Araceae, between them Aglaonema commutatum (Chinese evergreen); Spathiphyllum wallisii (Peace lily) and Scindapsus aureus (Epipremnum aureum). The last specie, after $24 \mathrm{~h}$ of exposition was able to remove $9.2 \%$ of trichloroethylene (TCE) and $73.2 \%$ of benzene and it is the same plant used in our study.

Some leaves experience equivalent pollutant absorption but can vary in resistance ability. In this sense Scindapsus aureus or Epipremnum aureum is considered a specie resistant to environmental pollution. However the mechanisms involved remain no know and this knowledge for each contaminant requires precise experimentation to identify pollutant byproducts responsible if any alteration occurs or to elucidate cellular sites with anti-pollutant activity. Ekschmitt and Korthals [14-16] have analyzed nematode genera about sensitivity or tolerant toward heavy metals and organic pollutants in six longterm field experiments. They provided a list of nematode genera potentially bioindicators for specific soil contaminants. Chiloplacus and Pratylenchus are good candidates for specific bioindication of $\mathrm{Cu}$; Paratylenchus and Criconemoides of $\mathrm{Cr}$, and Tylenchus and Cephalobus of $\mathrm{Zn}$, considering their exclusive and positive correlations with these metals [17-19]. Finally these authors reported that good candidates for bioindication of organic toxicants possibly can be found in the Family Hoplolaimidae.
Few studies using plants as air contamination biomarker by $\mathrm{CO}$ were conducted. The results obtained in this work allow recommend susceptible species for quantifying indirect pollution in offices, laboratories, factories, where the workers are exposed $8 \mathrm{~h}$ daily, during several years. We are expanding the research focused in other plants and pollutants, and also its applications derived from new knowledge [20].

\section{Acknowledgments}

The authors thank Consejo de Investigaciones-Universidad Nacional de Tucuman, (PIUNT 546); CONICET (PIP 0010) and AGENCIA (PICT 0804 y D-TEC) for their grants.

\section{References}

1. Hannemann F, Bichet A, Ewen KM, Bernhardt R (2007) Cytochrome P450 systems-biological variations of electron transport chains. Biochim Biophys Acta 1770: 330-344

2. Guengerich FP (2008) Cytochrome p450 and chemical toxicology. Chem Res Toxicol 21: 70-83.

3. Levitt J (1972) Responses of plants to environmental stresses. Academic press, New York.

4. Olry A, Schneider-Belhaddad F, Heintz D, Werck-Reichhart D (2007) A medium-throughput screening assay to determine catalytic activities of oxygenconsuming enzymes: a new tool for functional characterization of cytochrome P450 and other oxygenases. The Plant J 51: 331-340.

5. Wolverton BC, Anne J, Keith B (1989) Interior landscape plants for indoor ai pollution abatement. National Aeronautics and Space Administration (NASA).

6. Bradford MM (1976) A rapid and sensitive method for the quantitation of microgram quantities of protein utilizing the principle of protein-dye binding. Anal Biochem 72: 248-254. 
Citation: Cruz M, Fuentes M, Khouri E, Rollan G, Gonzalez SN (2018) Scindapsus aureus as Potential Biomarker of Polluted Environment. J Pollut Eff Cont 6: 221. doi: 10.4172/2375-4397.1000221

7. Khouri EA (2017) Evaluation of some parameters of atmospheric pollution in the NOA. Magister thesis. National University of Tucuman.

8. Rodríguez CEMR, Purata A, Cruz PH (2010) Cytochrome P450 biomarker for therapeutic toxicological carcinogenic exposure. REB 29: 39-52.

9. Tabrez S, Ahmad M (2013) Cytochrome P450 system as potential biomarkers of certain toxicants: comparison between plant and animal models. Environ Monit Assess 185: 2977-2987.

10. Werck-Reichhart D, Feyereisen R (2000) Cytochromes P450: a success story. Genome Biol 1.

11. Bak S, Beisson F, Bishop G, Hamberger B, Höfer R, et al. (2011) Cytochromes P450. The Arabidopsis Book/American Society of Plant Biologists 9: e0144.

12. Mizutani M (2012) Impacts of diversification of cytochrome P450 on plant metabolism. Biol Pharm Bull 35: 824-832.

13. Taylor GE (1978) Plant and leaf resistance to gaseous air pollution stress. New Phytol 80: 523-534.
14. Ekschmitt K, Korthals GW (2006) Nematodes as sentinels of heavy metals and organic toxicants in the soil. J Nematol 38: 13-19.

15. Fersth $A$ (1999) Structure and mechanism in protein science: a guide to enzyme catalysis and protein folding. (2ndedn), Freeman and Company, USA.

16. Klemz C, Salvo LM, Neto JCB, Bainy ACD, Assis HCS (2010) Cytochrome P450 detection in liver of the catfish Ancistrus ultispinis (Osteichthyes, Loricariidae) Braz Arch Biol Technol 53.

17. Kumar S (2010) Engineering cytochrome P450 biocatalysts for biotechnology, medicine, and bioremediation. Expert Opin Drug Metab Toxicol 6: 115-131.

18. Kumar S (2012) Challenges and opportunities of cytochrome P450-mediated phytoremediation. J Pet Environ Biotechnol 4: e001.

19. Kumar S, Jin M, Weemhoff JL (2012) Cytochrome P450-mediated phytoremediation using transgenic plants: A need for engineered cytochrome P450 enzymes. J Pet Environ Biotechnol 3: 100-127.

20. Omura T, Sato $R$ (1964) The carbon monoxide-binding pigment of liver microsomes I. Evidence for its hemoprotein nature. J Biol Chem 239: 2370-2378. 